\title{
Leadership and Employees Attrition in Manufacturing Companies
}

\author{
Dr. Shankar R \\ \{sr.hum@psgtech.ac.in \} \\ Assistant Professor, Department of Humanities, PSG College of Technology, Coimbatore
}

\begin{abstract}
Considering today's competitive market, managing an organization's competent and qualified human resources is critical to success. In order to attract staff, the industry usually raises executive compensation. It's a difficult task for any leader in charge of more than one staff in a corporation. Administrators are frequently untrained on how to keep employees from quitting. Employers view turnover as a loss of productive employees and talent. However, there's more to attrition than a shrinking population. Entrepreneurs take with them the necessary skills and qualifications they gained throughout their time as employees departing a company. Here is where leadership styles, as well as skills, play a critical influence in lowering attrition rates. The current study examines the impact of leadership styles on the many factors of attrition in the manufacturing sector in this context.
\end{abstract}

Keywords: Human Resource, Leadership Styles, Attrition, Manufacturing sector..

\section{Introduction}

Since the turn of the century, the field of leadership — both in theory and in practice has been a rapidly expanding part of management science. Leadership is a given and fundamental role in most concepts of management and organization in enforcing rules, inspiring personnel, and expressing future goals and visions to aim towards. In most companies, leadership is thought to offer a unique, important, and valuable difference to based intervention, and the role of the manager has consequently been consumed with the neverending work of discovering identities or practices associated with effective management. The area of organizational leadership has typically been leader-centered, focusing on the individual executives and their characteristics, skills, and deeds, and therefore putting the abstract phenomena of 'leadership' into separate individuals who are removed from their cultural context. This one was important in the early twentieth century's innovations in operations research, in which the greatest leaders were to be found and chosen based on their fitness and formal merits rather than pre-modern criteria like kinship or magnetism. The issue of determining what made a suitable leader remained unsolved, and this topic spawned a slew of diverse thought schools. One school of thought attempted to discover personality attributes that set great leaders apart from others. Others countered that leadership was about the interaction between leaders and followers, and also that different kinds of interaction had different outcomes.

In modern texts, a leader is characterized as a collective with special abilities to impact the group, and governance is therefore a series of complex interactions in which leaders 
inspire followers by developing shared meaningful visions of the future. The dividing line between transaction processing and revelatory governance, showing the difference between governance as a contracting party's leader and followers and leadership as a social relationship in which followers' aspirations is raised to those of the leaders themselves, is at the heart of the argument. In recent years, there seems to be a growing debate in the areas of leadership studies over shared and distributed leadership viewpoints, with the emphasis on leadership as a group activity rather than the actions of official leaders. Along with management decisions and entrepreneurship activity activities, the leaders are in a position to resolve all employeerelated problems. The galloping need for talented personnel throughout the last decade of the twenty-first century has had a crucial impact on all employment-related concerns in organizations experiencing employee attrition. Employers are particularly concerned about the implications for needs that go far beyond ground attrition and the repercussions on corporate performance, as well as the necessity for ongoing recruiting and the associated expenditures. When a person is employed, it is customary for him to remain working for the organization during his long career.

Consequently, once someone is fit for work in terms of the job circumstances and his standards, the employer that hires him is expected to provide him with work. This implies that associations are mutually and reciprocally interested in the definition and reinterpretation of their partnership structure. India is rapidly establishing itself as a global industrial hub. Either industrial enterprises, such as autos or computer components, durable goods, or technical goods, are manufactured in India by multinationals. According to a report by the Federation of Indian Chambers of Commerce and Industry (FICCI) and Yes Bank, India is on track to become the global manufacturing center for luxury goods in the next five years, with the development of luxury goods expected to be a US\$ 500 million industry. India possesses all of the requisite talents in product, process, and capital engineering because of its long manufacturing legacy and higher education institutions. India's low-cost, well-educated labor draws a wide range of businesses from various industries, transforming the country into a global manufacturing powerhouse. The enormous domestic sector in India, as well as the access to low labor with superior technological skills, has enticed a growing number of multinationals to establish manufacturing bases in the country.

Following the advent of globalization, the industry underwent a major transformation. The success of manufacturing and promotion is entirely dependent on skilled and well-trained employees. The company's retailers are given systematic training to help them increase their knowledge. However, following good training, workers demonstrate their abilities by aggressively exhibiting their abilities through violent performance. The flippant attitude or actions of important bosses create resentment, and smart and skilled salespeople depart their employment or resign swiftly. This creates a tremendous void as a result of their unexpected departure, and the company suffers greatly as a result of their absence. At the same time, massive financial losses were incurred in the development of new employers through detailed and meticulous planning. At this point, it's more necessary to figure out what's causing manufacturing attrition. At the same time, the damage done to the company's reputation and the prestige lost as a result of reference marketing by qualified employees had to be assessed. The worker who leaves the organization still spreads the negative comment through recommendation marketing and demonstrates the hostile work environment. This is also the chief's job to recognize and respond to worker complaints on a timely basis. The current research tries to find a solution to the research objective using the framework outlined above.

1. To investigate the impact of leadership on the elements that contributes to attrition in the Manufacturing sector. 


\section{Literature Samples}

Sudha et al. (2015) investigated why employees quit their jobs and made recommendations for retaining employees in the retail sector, with a focus on a study of selected organized stores in Salem, Tamilnadu. A total of 150 people were polled from ten well-organized Salem shops. According to the findings, there is a link between corporate objectives and retention, as well as numerous personal factors such as higher education, work development, popularity, and family, all of which have a major impact on the respondent's present employability.

The initial survey was conducted with a questionnaire survey among 156 employees questioned by Rajasshrie Pillai et al (2016) to explore the causes of workforce attrition. Controlled interviews were also conducted to have a better understanding of the HR experience. Their report also talked about the company's workforce goals. Their research focuses on managerial attrition reasons and planned store retention approaches.

\section{Methodology}

For the study, the top 10 manufacturing enterprises in Coimbatore based on turnover are chosen, from which the sample respondents are drawn. Purposive sampling is used to pick 200 respondents who are workers of the select companies. The study's data is obtained using structured questionnaires and sorted in a way that allow for analysis. The study has a restriction in that the data are only available for a specific place.

\section{Analyses and Discussion}

Kaiser-Meyer-Olkin (KMO) Measure of Sampling Adequacy

Table 1: KMO and Bartlett's Test

\begin{tabular}{|l|l|c|}
\hline \multicolumn{2}{|c|}{ Kaiser-Meyer-Olkin Measure of Sampling Adequacy. } & .937 \\
\hline \multirow{3}{*}{ Bartlett's Test of Sphericity } & Approx. Chi-Square & 265.31 \\
\cline { 2 - 3 } & $\mathrm{df}$ & 200 \\
\cline { 2 - 3 } & Sig. & .007 \\
\hline
\end{tabular}

The KMO value 0.937 states that the variables chosen for the study are positively correlated with the Bartlett's test of significance value at 0.07 and hence it is valid that Factor Analysis can be performed for the selected variable.

\section{Communalities}

Principal Component Analysis can be used to extract the communalities for the variable and that is followed as; 
Table 2: Communalities

\begin{tabular}{|l|l|l|}
\hline Factors & Initial & Extraction \\
\hline Induction and training & 1.000 & .631 \\
\hline Collective team work & 1.000 & .581 \\
\hline Leadership & 1.000 & .636 \\
\hline Innovation & 1.000 & .723 \\
\hline Lack of Recognition & 1.000 & .610 \\
\hline Quality of Supervision & 1.000 & .541 \\
\hline Control & 1.000 & .609 \\
\hline Job expectations vs reality & 1.000 & .617 \\
\hline Shifts in Management Strategies & 1.000 & .539 \\
\hline Career development & 1.000 & .555 \\
\hline Co-operation & 1.000 & .609 \\
\hline Family Welfare & 1.000 & .681 \\
\hline Representation & 1.000 & .630 \\
\hline Job Satisfaction & 1.000 & .646 \\
\hline Salary and Benefits & 1.000 & .591 \\
\hline Job environment & 1.000 & .599 \\
\hline Meeting deadlines & 1.000 & .668 \\
\hline Effective communication & 1.000 & .607 \\
\hline Initiative & 1.000 & .590 \\
\hline
\end{tabular}

Extraction Method: Principal Source: Primary data

This leads to the verification of individual variances has shown in the commonalities that the 19 variables have their variances ranging from 0.541 to 0.723 this implies the 19 variables are statistically significant.

\section{Rotated Component Matrix}

Rotated Component Matrix indicated the correlation of each variable with each factor. After factor analysis eight factors have been arrived from nineteen statements. Variable with high factor loading are considered first and have great importance. Such factors are identified and names are given for each factor as follows;.

Table 3: Rotated Component Matrix

\begin{tabular}{|l|l|l|l|l|}
\hline \multirow{2}{*}{ Factors } & \multicolumn{2}{|l|}{ Components } & \multirow{2}{*}{ Factor name } \\
\cline { 2 - 4 } & 1 & 2 & 3 & \\
\hline Orientation and initial training & .741 & & & \multirow{2}{*}{ In-house factors } \\
\hline Representation & .692 & & & \\
\hline Job Satisfaction & .662 & & & \\
\hline Salary and Benefits & .702 & & & \\
\hline
\end{tabular}




\begin{tabular}{|c|c|c|c|c|}
\hline Quality of Supervision & .631 & & & \\
\hline Job expectations vs reality & .663 & & & \\
\hline Shifts in Management Strategies & .602 & & & \\
\hline Co-operation & .639 & & & \\
\hline Lack of Recognition & & .589 & & \multirow{5}{*}{ General factors } \\
\hline Control & & 612 & & \\
\hline Career development & & .671 & & \\
\hline Family Welfare & & .599 & & \\
\hline Working environment & & .681 & & \\
\hline Collective team work & & & .625 & \multirow{6}{*}{ Personal factors } \\
\hline Leadership & & & .582 & \\
\hline Representation & & & .571 & \\
\hline Meeting deadlines & & & .509 & \\
\hline Effective communication & & & .600 & \\
\hline Initiative & & & .623 & \\
\hline
\end{tabular}

Extraction Method: Principal Component Analysis.

Rotation Method: Varimax with Kaiser Normalization. a. Rotation converged in 6 iterations.

From the above table it is shown that on the basis of given relationship, eight variables on first factor are loaded and those factors are named as in-house factors. On the Second Factor, five variables are loaded and they are named as general factors. On the Third Factor, six variables are loaded and named as personal factors.

Multivariate analysis of variance to test the impact of attrition on the development and productivity of selected companies

Multivariate Analysis of Variance has been used to analyze the significance of differences between the employees' attrition and the development and productivity of the selected companies.

$\mathbf{H}_{01}$ : There is no significant difference between leadership and factors of employees' attrition of the selected companies.

Table 4: Multivariate analysis of variance

General Linear Model: Leadership styles versus Employees' attrition

\begin{tabular}{|c|c|c|c|}
\hline \multicolumn{4}{|c|}{$\begin{array}{l}\text { MANOVA for Employees' attrition } \\
\mathrm{S}=2 \mathrm{~m}=-0.5 \mathrm{n}=100\end{array}$} \\
\hline Criterion & Test Statistic & $\mathbf{F}$ & $\mathbf{P}$ \\
\hline Wilk's & 0.58241 & 12.56213 & $0.00 * *$ \\
\hline $\begin{array}{l}\text { Lawley- } \\
\text { Hotelling }\end{array}$ & 0.41238 & 9.41241 & $0.00 * *$ \\
\hline Pillai’s & 0.72135 & 10.78412 & $0.00 * *$ \\
\hline Roy's & 0.44563 & & $0.00 * *$ \\
\hline
\end{tabular}


Source: Primary data

The table 2 presents the multivariate analysis between the leadership styles and employees' attrition. It is inferred that the $p$ values are being significant and lead to the rejection of null hypothesis and confined that the various leadership styles will have significant difference in the employees' attrition.

\section{Recommendation And Conclusion}

Over the previous decade, India's manufacturing industry has undergone various transformations, including a major shift in the nature and spread of the globalized economy. India has a robust industry, with clients from various socioeconomic groups all around the country. The proliferated growth of the organized retail business in India has also created the issue of workforce depletion. The huge issue of turnover has risen in today's different company cultures around the world. Workforce turnover has been a modest but steady stumbling block to an organization's growth and competitiveness. Companies must build comprehensive retention strategies to handle the high incidence of attrition. Employees must develop a clear grasp of the job profile and performance evaluation. When responsibilities, skills, and judgment must be dispersed over numerous individuals instead of one, leadership is best practiced as a cooperative and collective role. Finally, manufacturing enterprises in Coimbatore must encourage diversity and devise strategies to retain personnel in a variety of positions, ages, and functional areas by offering resources for their growth and reminding people that they're the only firm's most valuable and important asset.

\section{References}

[1] Alinibzberg 1980, Man and his Work: Managing People at Work, Macmillan Publishing Company Inc., New York.

[2] Alshahrani Ahmed Saeed, Alqahtani Abdulaziz Mubark and Alshahrani Bander Sayaf 2015, 'Exploring Human Resource Management System of Saudi Electricity Company', International Journal of Management Science and Business Administration, Vol.1, Issue 5, pp.25-40.

[3] Amarja Satish Nargunde 2013, 'Role of hr in retail sector in India', International Journal of Management, Vol.4, Issue 6, pp.221-226.

[4] Arunkumar 2017, A study oin employee attrition in organized retailing sector with reference to Coimbatore city, Ph.D.Thesis submitted to Anna University

[5] Chih Y, Kiazad K, Zhou L, Capezio A, Li M and Restubog S 2016, 'Investigating Employee Turnover in the Construction Industry: A Psychological Contract Perspective', Journal of Construction Engineering and Management, Vol.142, Issue 6.

[6] Lucia Crevani, Monica Lindgren, Johann Packendorff (2010), 'Leadership, not leaders: On the study of leadership as practices and interactions', Scandinavian Journal of Management, 26, 7786

[7] Rajasshrie Pillai, Ravi Teja Mamidi and Hamsini Kuchibhotla 2016, 'A Study of Employee Turnover and Retention Strategies in Organised Retail in Pune City', MERC Global's International Journal of Social Science \& Management, Vol.3, Issue 3, pp.83-87.

[8] Sudha P, Prasannakumaran C \& Aswini M M (2015), 'An empirical analysis on employee retention policies of selected organized retailers with special reference to Salem city, Tamilnadu', Asia Pacific Journal of Marketing \& Management Review, Vol.4, No.1, pp.24-35. 
[9] Vuyisile Mabindisa 2013, 'Impact of staff turnover on organizational effectiveness and employee performance at the department of home affairs in the eastern cape province', unpublished Disseration submitted to Durban University of Technology.

[10] Yamonaa Thevey 2014, 'A study on employee's turnover intention in banking industry', Thesis submitted to University Utara Malaysia, Kedah.

[11] Yongbeom Hur 2007, 'Organizational performance, turnover, and human resource management: Focusing on municipal police services', University of Kentucky Doctoral Dissertations Paper 524. http://uknowledge.uky.edu/gradschool_diss/524. Accessed on 24.03.2016. 